\title{
UPAYA MEMPERKECIL KESENJANGAN KOMPETENSI LULUSAN SEKOLAH MENENGAH KEJURUAN DENGAN TUNTUTAN DUNIA INDUSTRI
}

\author{
Nugroho Wibowo \\ SMK N 1 Saptosari Gunungkidul \\ Email: asyifahaifa3@gmail.com
}

\begin{abstract}
Vocational High Schools are concerned with human resources development to cope the requirements of fast developing market. Indonesian education is still not comprehensive as it emphasizes on the hard skills and neglects the soft skills and eventually the graduates find difficulty to compete in the workforce. In preparing competent human resources as expected by the industry, the prioritised programs to be undertaken by the Vocational High Schools are (1) conducting the teaching factory program; (2) collaborative programs with the industry that consist of: field practices, internship (on the job training), industrial visits, recruitments, industrial classes; and (3) stakeholders' guidance related to workforce.
\end{abstract}

Keywords: competency gap, industry demands, the competence of vocational schools graduates

\begin{abstract}
ABSTRAK
Sekolah Menengah Kejuruan (SMK) sebagai salah satu pemegang peranan penting dalam penyiapan tenaga kerja dituntut untuk selalu dapat mengikuti kebutuhan pasar yang terus berkembang. Sekolah yang ada di Indonesia belum membentuk lulusan yang mempunyai dua keterampilan yaitu hard skillsdan soft skillsdan pada akhirnya lulusannya akan sulit bersaing di dunia kerja.Dalam menyiapkan tenaga kerja yang berkompeten sesuai harapan industri, SMK dapat melaksanakan program-program kegiatan yaitu: (1) program teaching factory; (2) Jalinan kerjasama dengan industri yang berbentuk: pengelolaan prakerin yang baik, magang (on the job training), pengelolaan kunjungan industri, rekruitmen tenaga kerja, penyelenggaraan kelas industri; dan (3) Penyuluhan dan pembinaan dari stake holder terkait dengan ketenagakerjaan.
\end{abstract}

Kata kunci: kesenjangan kompetensi, kompetensi lulusan SMK, tuntutan industri

\section{PENDAHULUAN}

Pada tahun 2015 seluruh negara yang berada dalam kawasan ASEAN akan memulai sebuah hubungan kerjasama yang menjadi sebuah pencapaian baru dalam sejarah hubungan kerjasama internasional di ASEAN, yaitu Asean Free Trade Area (AFTA) yang akan dimulai pada akhir tahun 2015 (Ramadhiani, 2014) AFTA merupakan wujud kesepakatan dari negara-negara ASEAN untuk membentuk suatu kawasan bebas perdagangan dalam rangka meningkatkan daya saing ekonomi kawasan regional ASEAN dengan menjadikan ASEAN sebagai basis produksi dunia serta menciptakan pasar regional bagi penduduk di kawasan tersebut. Pengaruh AFTA dalam sistem pendidikan Indonesia sudah dapat dirasakan hari ini. Pemerintah dihadapkan pada sebuah tantangan besar untuk membuat kebijakankebijakan yang mendukung untuk menyiapkan tenaga kerja Indonesia yang mampu bersaing untuk melewati tantangan AFTA 2015. Sekolah Menengah Kejuruan (SMK) sebagai salah satu pemegang peranan yang penting dalam penyiapan tenaga kerja dituntut untuk selalu dapat mengikuti kebutuhan pasar yang terus berkembang. Peraturan Pemerintah Republik 
Indonesia No. 29 Tahun 1990 tentang pendidikan menengah pasal 3 ayat 2 juga menyebutkan bahwa SMK mengutamakan penyiapan siswa untuk memasuki lapangan kerja serta mengembangkan sikap profesional.

Kenyataan di lapangan menunjukkan bahwa keberadaan SMK saat ini dinilai masih kurang dalam penyiapan lulusannya sebagai tenaga siap kerja. Dani Wardani (Callan, 2003 dan Clarke, 2007) mensinyalir bahwa ada perbedaan tujuan antara dunia pendidikan dengan dunia industri karena dunia sekolah menginginkan lulusan yang mempunyai nilai yang tinggi dalam waktu yang cepat sedangkan dunia industri menginginkan lulusan dengan kompetensi teknis dan sikap yang baik.

Kenyataan di atas dibuktikan dengan jumlah pengangguran yang ada di Indonesia. Berdasarkan data BPS yang berkaitan dengan hal di atas pada Agustus 2013 lulusan SMK yang menganggur mencapai 11,21 persen terhadap jumlah pengangguran terbuka, dan persentase tersebut merupakan angka tertinggi disusul lulusan SMA sebesar 9,55 persen, lulusan SMP sebesar 7,15 persen, lulusan diploma sebesar 6,14 persen, lulusan dari universitas sebesar 5,65 persen dan yang terakhir dari lulusan SD menyumbang 3,04 persen (Suryowati, 2013). Hal di atas menunjukkan belum adanya link and match antara sekolah dan industri sehingga lulusan SMK belum terserap di dunia industri, kompetensi lulusan SMK yang diharapkan oleh industri belum terbentuk dengan baik.

Kompetensi yang diharapkan oleh industri adalah keterampilan sesuai dengan bidangnya (hard skill) dan kompetensi sikap, kerjasama, motivasi yang tergolong dalam soft skill. Ratarata sekolah yang ada di Indonesia belum membentuk lulusannya untuk mempunyai dua keterampilan di atas dan pada akhirnya lulusannya akan sulit bersaing di dunia kerja. Belum adanya kesamaan visi di atas antara sekolah dan industri menjadikan penulis ingin memberi gambaran cara meminimalisir celah antara lulusan SMK dengan tuntutan industri. Paparan di atas menunjukan masalah yang berkaitan dengan kesenjangan antara SMK dengan industri yaitu: (a) Tantangan AFTA membutuhkan penyiapan tenaga kerja yang kompeten yang dibutuhkan oleh industri. (b) Ada celah antara kompetensi yang dibutuhkan industri dengan lulusan yang dihasilkan oleh SMK. (c) Lulusan SMK belum mempunyai dua kompetensi pokok yang dibutuhkan oleh industri yaitu kemampuan hard skills dan soft skills atau terkadang hanya salah satu yang dikuasai lebih baik.

Berdasaran permasalahan di atas maka akan muncul pertanyaan bagaimana cara yang harus dilakukan SMK untuk memperkecil jarak kompetensi antara lulusan SMK dengan kebutuhan industri. SMK merupakan salah satu dari penyelenggara pendidikan. SMK sebagai salah satu lembaga pendidikan kejuruan memiliki tugas mempersiapkan peserta didik untuk dapat bekerja sesuai bidang keahlian. SMK merupakan salah satu bentuk satuan pendidikan formal yang menyelenggarakan pendidikan kejuruan di Indonesia pada jenjang pendidikan menengah sebagai lanjutan dari SMP, MTs atau bentuk lain yang sederajat. Sekolah di jenjang pendidikan dan jenis kejuruan dapat bernama SMK atau Madrasah Aliyah Kejuruan (MAK) atau bentuk lain yang sederajat.

Tujuan pendidikan menengah kejuruan menurut Undang-undang Nomor 20 Tahun 2003, terbagi menjadi tujuan umum dan tujuan khusus. Tujuan umum pendidikan menengah kejuruan adalah untuk (a) meningkatkan keimanan dan ketakwaan peserta didik kepada Tuhan Yang Maha Esa; (b) mengembangkan potensi peserta didik agar menjadi warga Negara yang berakhlak mulia, sehat, berilmu, cakap, kreatif, mandiri, demokratis dan bertanggung jawab; (c) mengembangkan potensi peserta didik agar memiliki wawasan kebangsaan, memahami dan menghargai keanekaragaman budaya bangsa Indonesia; dan (d) mengembangkan potensi peserta didik agar memiliki kepedulian terhadap lingkungan hidup dengan secara aktif turut memelihara dan melestarikan lingkungan hidup, serta memanfaatkan sumber daya alam dengan efektif dan efisien. 
Proses pembelajaran di SMK menuntut siswa mempunyai tiga ranah kompetensi yaitu kognitif, afektif, dan psikomotorik. SMK dituntut harus mampu menciptakan Sumber Daya Manusia (SDM) yang dapat beradaptasi dengan kemajuan ilmu pengetahuan dan teknologi. Dalam proses pembelajaran di SMK tugas utamanya adalah pencetak tenaga kerja yang siap pakai harus membekali peserta didik dengan pengetahuan dan keterampilan yang sesuai dengan kompetensi program keahlian masing-masing.

Lulusan SMK berperan dalam memenuhi kebutuhan dunia kerja sebagai tenaga kerja tingkat menengah, selain diharuskan menguasai kompetensi sesuai bidang juga harus mampu melakukan pengembangan diri sebagai upaya agar tetap mampu berkompetisi pada saat ini maupun masa yang akan datang menyesuaikan tuntutan jaman. SMK membekali lulusannya dengan kemampuan kognitif (pengetahuan) dan kemampuan psikomotorik atau keterampilan (skill). Ranah berikutnya adalah adaptif, tujuannya adalah membekali lulusannya dengan kemampuan adaptif, yaitu kemampuan untuk melakukan penyesuaian dan pengembangan diri sesuai dengan perkembangan teknologi dan industri yang ada. Kompetensi adaptif yang diberikan berupa materi pengetahuan dasar di bidang teknologi sesuai dengan bidang masingmasing.

Proses pendidikan di SMK merupakan pembelajaran untuk menyediakan sumber daya insani yang mempunyai daya saing secara internasional karena tantangan internasional lebih mendominasi di tahun-tahun yang akan datang. Untuk itu perlu ada upaya atau strategi dan kebijakan yang perlu dilakukan sebagai antisipasi bagi perbaikan dan pengembangan proses pendidikan. Dunia industri sebagai pengguna dari lulusan pendidikan kejuruan atau pendidikan profesional lainnya senantiasa melihat dan menaruh perhatian yang amat besar padakompetensi sumber daya manusia itu. Tripathy dalam Pramudi Utomo (2011) menjelaskan semua pekerja pada dunia industri yang berskala internasional mempersyaratkan penguasaan landasan-landasan kompetensi dan keterampilan dengan kinerja tinggi. Meskipun demikian bagi sebuah perusahaan, tidak semua pekerja dengan hard skills yang dimiliki dapat menjamin kesuksesan perusahaan dengan laba yang banyak. Secara umum beberapa industri menginginkan lulusan yang mempunyai dua kompetensi pokok yaitu hard skills dan soft skills. Kompetensi hard skills merupakan keterampilan yang digunakan untuk bekerja sesuai bidang keahlian, sedangkan kompetensi soft skills digunakan untuk mendukung pekerja menyelesaikan tugasnya. Keterampilan pokok dipelajari ketika lulusan berada di SMK lewat proses pembelajaran sedangkan soft skills selain di sekolah juga dapat diajarkan dengan pembiasaan di sekolah maupun lingkungan luar sekolah. Lebih lanjut Patric S O’Brien (1997) menjelaskan soft skills meliputi communication skill, organizational skill, leadership skill, logic skill, effort skill, group skill dan ethic.

Kunci pokok pengembangan SMK terletak pada manajemen sekolah. Sekolah seharusnya melakukan proses perencanaan, pelaksanaan dan evaluasi terhadap semua kegiatan yang ada di sekolah. Kerjasama sekolah dengan industri adalah suatu keharusan oleh sebuah SMK, karena beberapa kegiatan sekolah selalu melibatkan dunia industri misalnya praktik kerja industri (Prakerin), on job training (OJT), kunjungan industri dan sebagainya. Peran industri juga dituntut untuk lebih dalam terlibat dalam kegiatan-kegiatan tersebut, terkadang industri yang terlibat tidak terlalu berperan banyak karena industri biasanya mempunyai polapikir pragmatis terhadap keuntungan bisnis.

Manajemen sekolah harus mempunyai strategi yang mengakomodir kepentingan kedua belah pihak agar kerjasama dengan industri dapat berjalan dengan berkesinambungan dan. Lancer. Penyamaan visi kerjasama dalam berbagai bentuk kegiatan harus bertujuan sama yaitu menyediakan lulusan yang sesuai dengan dunia kerja. Bentuk-bentuk kegiatan di sekolah yang dapat memperkecil celah antara SMK dengan industri diantaranya program teaching factory dan jalinan kerjasama dengan industri 
yang berbentuk pengelolaan prakerin yang baik, magang (OJT), pengelolaan kunjungan industri, rekruitmen tenaga kerja, penyelenggaraan kelas industri; dan penyuluhan dan pembinaan dari stake holder terkait dengan ketenagakerjaan.

Kegiatan teaching factory terdiri dari dua prinsip utama yaitu pembelajaran berbasis kompetensi dan pembelajaran berbasis produksi. Pembelajaran berbasis kompetensi menurut Graeme Dobson yang dikutip Nuryake Fajaryati (2012) adalah pembelajaran yang bertujuan untuk membantu peserta didik memperoleh ketrampilan dan pengetahuan sehingga mampu melakukan tugas sesuai dengan standar yang telah ditentukan. Prinsip yang kedua adalah pembelajaran berbasis produksi. Harianto dan Saefudin dalam Nuryake Fajaryati (2012) menyatakan bahwa pembelajaran berbasis produksi berarti siswa terlibat dalam proses produksi.

Bentuk kongkrit teaching factory di sekolah yang ada di Indonesia adalah penyediaan produksi dan jasa sesuai dengan kompetensi yang ada di sekolah tersebut atau dinamakan Unit Produksi dan Jasa (UPJ). Pengelolaan UPJ yang ada di sekolah selama ini belum optimal karena belum menggabungkan kedua prinsip pembelajaran yaitu pembelejaran berbasis kompetensi dan pembelajaran berbasis produksi. Langkah-langkah yang harus dilakukan agar pengelolaan UPJ berjalan sesuai dengan tujuan yang ingin dicapai adalah melalui pengelolaan pembelajaran untuk meningkatkan kompetensi yang sesuai dengan dunia industri meliputi: (1) Proses pembelajaran keterampilan yang dirancang berdasarkan prosedur dan standar yang sesungguhnya. (2) Setting pembelajaran dibuat sesuai dengan kenyataan yang ada di industri. (3) Pembelajaran berpusat pada student active learning dan learning by doing. (4) Merancang pembelajaran untuk tujuan pembelajaran yang meningkatkan kemampuan soft skills (mandiri, kerjasama, pantang menyerah, tanggung jawab dan sebagainya). (5) Mensosialiasikan kegiatan pembelajaran ke seluruh stake holder sekolah agar menjadi satu pemahaman tujuan. (6) Melakukan evaluasi secara periodik terhadap pembelajaran yang berbasis teaching factory.

Langkah lain yang harus dilakukan adalah Pengelolaan kegiatan produksi yang dapat dilakukan dengan: (1) Sekolah menjalin kerja sama dengan industri untuk kepentingan job order dan pemasaran produk siswa. (2) Sekolah melakukan perencanaan dengan menganalisis jenis-jenis kegiatan yang laku atau berprospek menjadi keuntungan di lingkungan sekolah. (3) Sekolah melakukan perencanaan meliputi: pembentukan tim, program kerja, kebutuhan pengadaan alat dan bahan, perencanaan harga, dan program pemasaran produk atau jasa. (4) Sekolah melakukan pemantauan (quality control) pada pelaksanaan produksi dengan kualitas sebagai bahan patokan. (5) Sekolah melakukan evaluasi secara periodik terhadap pelaksanaan teaching factory, misalnya produk yang dihasilkan, evaluasi harga, bentuk kerjasama pemasaran dengan industri dan lainlain. Sinergi antara kedua kegiatan yaitu kegiatan pembelajaran dan kegiatan produksi diperlukan untuk pengembangan teaching factory kearah yang lebih baik. Hal tersebut memerlukan kerjasama yang partisipatif antar seluruh warga sekolah.

Bentuk kerjasama antara SMK dengan industri yang selama ini dilakukan oleh sekolahsekolah adalah berbentuk pelaksanaan kegiatan Prakerin. Sekolah memberikan kepercayaan terhadap industri untuk membimbing siswa mencapai kompetensi sesuai dengan kurikulum. Pengelolaan kegiatan ini terkadang belum optimal karena proses monitoring pembimbing sekolah terbatas, untuk itu diperlukan langkahlangkah pengelolaan Prakerin yaitu: (1) sekolah melakukan pendataan dan mengevaluasi tempat atau lokasi yang standar karena terkadang pencarian lokasi dilakukan oleh siswa dan sekolah tidak mengontrol kegiatan tersebut. (2) sekolah melakukan pembekalan prakerin yang berisi gambaran nyata akan pekerjaan dan sikap yang harus dilakuan selama prakerin. (3) sekolah melakukan pembimbingan secara periodik minimal satu bulan sekali. (4) evaluasi periodik terhadap kualitas pembelajaran di 
industri minimal satu bulan sekali. Kegiatan magang bertujuan untuk meningkatkan kemampuan sesuai dengan perkembangan teknologi yang terus berkembang, sekolah sebaiknya menjalin kerjasama dengan industri agar bersedia menyediakan waktu untuk dunia pendidikan jika terdapat teknologi baru yang diciptakan.

Bentuk kegiatan nyata yang dapat dilihat oleh siswa adalah kegiatan kunjungan industri, dimana siswa secara langsung berkunjung ke industri untuk melihat proses produksi yang dilakukan mulai dari persiapan produksi sampai dengan pasca produksi. Sebaiknya sekolah menjalin kerjasama yang baik dengan industri yang berskala nasional atau internasional sebagai lokasi kunjungan.

Kelas industri adalah kegiatan yang bertujuan supaya siswa dapat mengikuti pembelajaran sesuai dengan kegiatan nyata di industri, dalam hal ini sekolah dituntut mendatangkan industri yang mau memberikan pendidikan di sekolah dan tindak lanjutnya biasanya pada rekruitmen tenaga kerja. Kurikulum dalam kelas industri disusun oleh sekolah dan industri, peran industri disini dituntut untuk menskenario proses pembelajaran yang menghasilkan lulusan yang sesuai dengan tuntutan dunia kerja.

Kegiatan yang sangat bermanfaat lainnya adalah Rekruitmen Tenaga Kerja. Peran Bursa Kerja Khusus (BKK) sangat penting dalam proses rekruitmen tenaga kerja, sekolah melalui BKK sebaiknya menjalin kerjasama dengan industri sehingga industri bersedia menjadi tempat bagi lulusan untuk bekerja. Jalinan kerjasama rekruitmen dengan industri sebaiknya secara terus menerus dan selalu dievaluasi secara periodik agar terus dapat berjalan sesuai rencana.

Lembaga-lembaga terkait yang langsung berhubungan dengan tenaga kerja adalah Departemen Tenaga Kerja, lembaga tersebut berwenang untuk memberikan informasi, pelatihan, dan penyaluran teaga kerja. Sekolah sebaiknya menyiapkan siswa yang akan lulus tentang aturan-aturan tenaga kerja dan proses penyaluran agar siswa mempunyai gambaran tentang proses ketenagakerjaan yang sesuai dengan aturan. Bentuk kegiatan-kegiatan tersebut diantaranya: (a) Sosialisasi aturanaturan dan proses rekruitmen ketenagakerjaan. (b) Penyiapan kompetensi soft skills dalam menyongsong dunia kerja. (c) Pendidikan dan pelatihan calon tenaga kerja, dan (d) penyaluran tenaga kerja baik ke dalam maupun keluar negeri.

\section{SIMPULAN}

Langkah kongrit yang dapat dilakukan sekolah untuk memperkecil kesenjangan antara SMK dengan industri terkait bidang kompetensi lulusan. SMK adalah menyiapkan tenaga kerja yang berkompeten baik dari segi hard skills maupun soft skills sesuai harapan industri, SMK dapat melaksanakan program-program kegiatan sebagai berikut: (1) program teaching factory (2) pengelolaan prakerin (3) pengelolaan kunjungan industri (4) penyelenggaraan kelas industri. (5) program on job training, dan (6) penyuluhan serta pembinaan dari stake holder terkait dengan tenaga kerja.

\section{DAFTAR RUJUKAN}

Arimbi Ramadhiani. 2014. AFTA 2015 Menguntungkan Pengembang Lokal. Kompas online, Oktober 2014

Callan,VJ. 2003. Generic Skills Understanding Vocational Education and Training Teacher and Student Attitudes. Adelaide: NCVER

Clarke, M. 2007. Understanding and Managing Employability in Changing Career Contexts. Journal of European Industrial Training. Vol 32 nomor 4, 258-284

Depdiknas. 1990. Peraturan Pemerintah Nomor 29, Tahun 1990, tentang Pendidikan Menengah 
Depdiknas. 2003. Undang-undang RI Nomor 20, Tahun 2003, tentang Sistem Pendidikan Nasional

Fajaryati, Nuryake. 2012. Evaluasi Pelaksanaan Teaching Factory SMK di Surakarta. Jurnal Pendidikan Vokasi. No 2 Volume 3 Tahun 2012

O'Brien, PS. 1997. Making College Count: A real World Look at How to succeed in and After College. USA: Graphic Management Corp

Suryowati, Estu. 2014. Mencetak Lulusan yang Diharapkan Industri. Artikel. Diambil tanggal 27 April 2015 dari http://bisnis keuangan.kompas.com
Utomo, Pramudi. 2011. Peranan SDM Unggul Berkarakter dan Tuntutan Dunia Industri Makalah. Diambil tanggal 27 April 2015 dari http://staff.uny.ac.id/sites/default/ fi les/131576241/mklh_semnas2011_SDM \%20dan\%20Tuntutan\%20Industri.pdf

Wardani, Dani. 2011. Kontribusi Ketrampilan Sosial Dalam Pembelajaran IPS Terhadap Kesiapan Kinerja Praktek Kerja Industri. Jurnal UPI. Edisi Khusus No. 2 Agustus 201 